\title{
Queer and COVID-19 Positive Contagion, Suspicion, and Stigma
}

Holly Zwalf

Independent Researcher

Samantha Sperring

University of Technology Sydney

\begin{abstract}
I was one of the earliest cases of COVID-I9 in Australia. When I infected my partner, a trans man with cystic fibrosis, he was nine months pregnant. He birthed the baby during our nine days of forced isolation in hospital, making medical history as the first COVID-positive person to give birth outside of China, and the first documented non-caesarean birth in the world. Unfortunately, this was not the happy event it should have been. Our experiences while in the hospital were deeply traumatic, and since recovery we have been subjected to ongoing stigma. The post-COVID body is "othered" by medical professionals and the general public, treated with an acute suspicion reminiscent of ableism or fatphobia towards non-normative bodies. These experiences of exclusion and alienation echo the stigma directed towards the HIV-positive community during the height of the AIDS epidemic and the historical bio-medical regulation of queer bodies as second-class citizens. Drawing on theories of queer temporality, we consider the liminality of living in a "postCOVID" body — on the threshold of wellness and social contagion — as a queer time-warping experience. We call into question normative narrations of healthy/diseased bodies by considering the post-COVID body's treatment as continually contagious.
\end{abstract}

Keywords: contagion; queer; COVID; AIDS; pandemic; temporality

Résumé: J'ai été l'une des premières personnes à être diagnostiquée avec la COVID-I9 en Australie. Lorsque j'ai infecté mon partenaire, un homme trans atteint de fibrose kystique, celui-ci était enceinte de neuf mois. Il a accouché pendant la période d'isolement forcé de neuf jours que nous avons passée à l'hôpital, entrant ainsi dans l'histoire de la médecine comme la première personne COVID-positive à accoucher en dehors de la Chine et la première à accoucher sans césarienne dans le monde. Malheureusement, l'événement n'a pas été 
aussi heureux qu'il aurait dû l'être. Notre expérience à l'hôpital a été profondément traumatisante et, depuis notre guérison, nous faisons l'objet d'une stigmatisation permanente. Le corps post-COVID est «altérisé» par les professionnels de la santé et le grand public, faisant l'objet d'une forte suspicion qui rappelle le validisme ou la grossophobie visant les corps non normatifs. Cette expérience d'exclusion et d'aliénation fait écho à la stigmatisation qui a touché la communauté séropositive au plus fort de l'épidémie de sida et à la régulation biomédicale historique des corps queer en tant que citoyens de seconde zone. En nous appuyant sur les théories de la temporalité queer, nous abordons la liminalité propre à la vie dans un corps “post-COVID" - à la lisière entre bien-être et contagion sociale - comme une expérience queer de distorsion temporelle. Nous remettons en cause les récits normatifs sur les corps sains/malades en examinant le traitement du corps postCOVID comme continuellement contagieux.

Mots-clés: contagion; queer; COVID; sida; pandémie; temporalité

$I^{2}$

was at a party when it started. A slow creeping feeling, the tendrils of fever crawling down my back, up my skull, and squeezing my bones til they ached. It was the $29^{\text {th }}$ of February and my friend's fortieth birthday, though due to the scarcity of leap years we mocked him that it was actually only his tenth. Two days earlier I had gotten off a plane from the UK, so everyone was joking that I might have "it," waving Corona beers merrily in the air. No one really thought I did, least of all me. I had flown home from the UK earlier than planned - missing the reason for my trip, my grandmother's funeral-because my partner, a transgender man who was eight-and-a-half months pregnant, had had a minor car accident and was worried the shock was sending him in to early labour. I thought I was making a heroic choice, but it turned out to be anything but. The virus itself did not affect us particularly badly, but for nine days we were held in quarantine in hospital, not allowed to leave. What ensued was a series of dehumanizing events that left our family broken and deeply traumatised. During this time my partner also birthed his baby, making medical history as the first COVID-positive person to give birth outside of China, and the first documented non-caesarean COVID birth in the world.

This paper draws on the autoethnographic accounts of one of the author's experiences with contracting COVID-I9, in particular her experiences of stigmatisation post-COVID. We describe the effect of this ongoing stigma as placing her family in a state of perpetual social quarantine, thereby breaking with the traditional conventions of contagion by treating the body as permanently contagious (despite the family having produced satisfactory negative test 
results). We review this sense of continual contagion through a queer temporality lens, highlighting the liminality of living in a "post-COVID" body, on the threshold of wellness and social contagion, as a queer time-warping experience (Stacey and Bryson 2012). We trace the warped temporalities of COVID-I9, exploring its queer dimensions by way of tracing her queer family's infection with and recovery from the virus. In closing, we outline the points in which the author's experiences with post-COVID stigma converge and diverge with the stigma suffered by HIV patients during the AIDS epidemic, a stigma which we reconfigure as a state of "queer quarantine" within both political and health contexts.

Before exploring the intersections of stigma, sexuality, and the COVID-I9 pandemic, it is first important to clarify the use of the word queer. Queer has been used in three different but interlocking ways in this paper: as a descriptive word for the author's personal sexuality, as a descriptor of the wider LGBTQ+ community within which she moves and interacts, and as a field of critical theory. It is important to note, however, that the umbrella term "queer community" does not necessarily encompass the many LGBTQ+ people from racialized, disabled, or otherwise marginalized groups who are precluded by such a predominantly white middle-class homonormative scene (Allen 20I6; Morgensen 20I6).

It is also important to note that this paper utilizes autoethnography as its primary methodology. Autoethnography is described by Newmahr as reflexive writing which requires that the "self" be treated as the focus of the work (2OII, I6), the benefits being that the ethnographer is then able to "connect the personal to the cultural" (Gobo 62). Similarly, the rich ethnographic descriptions of the experiences of one of the authors of this paper serve to present the human face of the stigma suffered by COVID-survivors, an essential angle when examining the impact a COVID diagnosis can have on mental health-particularly for populations considered already "at risk."

Contagion suggests a temporal orientation. Borrowing from Stacey and Bryson's theorizing on the queer "time warp" of cancer survivorship, it relies on a before and an after in that "it speaks to the endurance of past trauma and looks forward to a future that it wills into being through the overcoming of adversity" (Stacey and Bryson 20I2, 5). The author's story, therefore, calls into question normative narrations of healthy/diseased bodies by drawing attention to the ways in which the post-COVID body is treated as continually contagious, "othered" by medical professionals, educators, the general public, and by friends and family. This treatment has echoes in the impact of homophobia, ableism, racism, or fatphobia on non-normative bodies or sexualities. It is also 
reminiscent of the experiences of exclusion, alienation, suspicion and stigma directed towards the HIV-positive community during the height of the AIDS epidemic, and the historical bio-medical regulation of queer bodies as secondclass citizens. Just as queer theorising on AIDS has reshaped relationships among identity, contagion, and death, it offers a means of understanding how this viral and psychic crisis reformulates the subject, and reinstates identity as a highly ambivalent site (Argüello 2016).

In the process of conceiving and writing this article, global protests over the racist violence committed against BIPOC communities have taken place in support of the \#blacklivesmatter movement. They have sought widespread accountability for structural white supremacy, police, and state violence, as well as disproportionate fatalities from COVID-I9. Intersections of gender, class, and age further compound the impacts of COVID-I9. Rates of domestic, sexual, and gender-based violence have increased substantially; those who suffer disproportionally from poverty, inadequate housing, and limited access to health care are less able to follow safety protocols (self-isolation, working from home, remaining "home" at all), face excessive policing, and are dying at alarming rates. The elderly and disabled, whether isolated or in group homes, are also disproportionately impacted. The family in this paper's autoethnographic accounts is mixed race and two of the three children are Dutch/African American, one with disabilities. While the intersection of these social locations did influence this family's experience of COVID-I9, as Morgensen notes, queer work can be susceptible to reproducing the colonial conditions that contextualize the practitioners of queer anthropology and their inquiries. As a method, queer anthropology therefore offers a space "not to withdraw from language, but to interact with it as a medium that may perform its own limits while acknowledging that which exceeds it" (Morgensen 2020, 613). Consequently, as authors we want to acknowledge both our own positionalities as white, cis-gendered, nondisabled, middleclass, queer women. This is one story of COVID-I9 among many, and we do not wish to discount the complexities faced by communities beyond our own.

\section{The Contagion Continuum}

I was the fifteenth case of COVID-I9 in Queensland, the state I live in in Australia. My pregnant partner, who also has cystic fibrosis, was the sixteenth. In those early days any confirmed case in Australia was legally required to be quarantined in hospital, so we were detained in negative-pressure rooms in hospital along with our kids. During the nine days we were held there, there were marked inconsistencies regarding our 
perceived contagion. Medical and cleaning staff avoided entering our room, social workers called on the phone rather than coming near us, and we were denied visits from our extended family. However, at other times, such as when I was permitted to leave my room to be present during my partner's birth, my mother was brought in to babysit my child in my room and was not given any personal protective equipment to wear. Despite both being positive, my partner and I were held in separate rooms, along with our respective children, and we were not allowed to visit each other. Whether this was due to concerns that we would infect the hallways as we walked the short stretch between each other's rooms, or due to other more sinister reasons (I cannot help but wonder whether a married heterosexual couple would have been treated the same way), I will never know. All I do know is that it began to feel as though we were being viewed as a virus and not as human beings with essential emotional needs.

Five days in to our time in hospital my partner birthed his baby. As we were trailblazers in this area there were huge concerns for the baby's health. We were aware that in China they had been conducting mandatory caesareans, removing the infant at birth, and denying the parent the chance to breast/chestfeed to reduce the risk of infection. Thankfully, after a great deal of negotiation with a team of specialists, everyone agreed that these steps would not be necessary, and I was also allowed to be present at the birth. The midwives and I were all masked and gowned, though they allowed my partner to labour without a mask as they were concerned it would impede his breathing. I was instructed to wear gloves when I delivered the baby onto his chest, but in a moment of craving skin-to-skin contact I refused to put them on and then spent the next few days worrying that I had made an irresponsibly dangerous decision. Fortunately the baby was born healthy. After a couple of hours it was time to leave the birthing suite and move to a room on the maternity ward, and at this point I was told I was not allowed to go with them, and that I had to return to my own room. I was taken back to my ward via the stairs to avoid using the lift, as they did not want me to have close contact with anyone, and my escort opened all the doors to prevent me touching anything. The following day my requests to visit my partner and his newborn were refused. I became distressed and threatened to leave my room, risking arrest in the process. Thankfully they moved him to the room next to mine that evening and I was finally able to see them. Over the following days my child and I were allowed to visit every day, following strict safety procedures. And then overnight it all changed again.

My partner and I were both still COVID-positive but the legal understanding of our contagion shifted rapidly when the government became concerned that they would not have enough hospital beds for critical cases. The law was swiftly altered and just after breakfast one morning we were informed that we were now allowed to finish our 
quarantine at home. We packed and prepared to leave in a state of excitement and relief, and then sat down to wait, assuming there would be an elaborate exit involving chaperones and cleared corridors, similar to our arrival. But no one came, and eventually they simply opened our doors and told us we were told we were free to leave, without an escort. We were allowed to go into the lifts with the general public, completely unattended, and to touch anything we wanted to touch. Our contagion risk had not changed at all from the previous day, when I had had to wash my hands, double bag all of our belongings, and carry my child to make sure they did not touch anything as we were escorted the five metres from our room to my partner's room next door for our daily visit. And yet now, less than 24 hours later, all that was required was that we wear masks as we walked freely around the hospital. The disjuncture between our legal and actual contagion was perplexing.

My partner and I live separately, so we completed another three weeks of isolation in our respective homes, and when our quarantine period was finally over and we were declared negative we ventured back into society feeling heroic. We had survived coronavirus and we were proud. I even talked about getting "kiss me, I'm immune" shirts made. We were completely unprepared for the hostile reception from our small town, and the lack of mistrust surrounding our newly non-contagious status, as we soon began to feel the sting of post-COVID stigma. People moved away from us in the shops, our children's kindergarten enrolment remained suspended until the following term, builders refused to finish essential work in our home, and we even had a GP treat us nervously when our COVID story came up during an unrelated appointment.

My partner and I both live in small country towns in regional Queensland, and while there is a large alternative community in the area, as is usually the case outside of cities, the majority of the population is conservative. There is one other rainbow family in my town and none in my partner's. Therefore as queers we were already accustomed to the "othering" we experienced as COVID survivors, the exclusion and alienation reminiscent of the social contagion with which queer bodies are already inscribed (in particular those who are not white or cis gendered). Understanding the queer body as inherently contagious, Plummer and McCann note that "twentieth century political discourses on sexuality ... are founded on deep-seated fears of 'different' sexualities as transmissible and dangerous" $(2007,43)$. Queer bodies pose a threat to "public space, healthy bodies, and the future of the nation" (Balogh 2015, ii) and are consequently seen as something "...to be neutralized, eliminated, or cured ...[the] contagion de-regulat[ing] categories of health and disorder, while also and at the same 
time, anticipating the increased regulation and surveillance of bodies, minds and movements" (Fritsch and McGuire 20I8, ix). The response to this is generally to regard queer bodies with suspicion, in effect containing or quarantining these bodies both socially and politically in order to prevent further contamination, as we will discuss later in this paper.

My family's otherness first became apparent the day I enrolled my child in daycare. I had recently relocated to regional Queensland from a major Australian city, and I was uneasily aware that I was one of the first rainbow families to have gone through the school. When I approached the principle to suggest some age-appropriate ways to promote discussions around diverse genders and sexualities my suggestions were turned down and I was told it was not necessary. I had the distinct impression that the school was not interested in creating space for our family. A year later, then, when the principle heard about our COVID diagnosis and contacted me to strongly suggest that our enrollment be suspended until the following term, an overly cautious timeframe considering we were declared negative with a month of classes still to go, I again felt as though our family was being dismissed.

This feeling of otherness was heavily weighted in my queer identity, but there are also other correlations to be made. This theory of contagion is widely applicable regarding a variety of non-contagious factors such as race, class, fat bodies, and disability. Just as homophobia seeks to contain queers, fatphobia seeks to pull fat people into line, and eugenics seeks to prevent the "contamination" of the biological pool by hereditary disabilities (Fritsch and McGuire 20I8, ix). Crip theorists Gibson (2018) and Ebben (2018) each describe disability, specifically autism, as being used to justify the containment of neural atypical people, and the intersections of disability and race have functioned as a rationale for eugenic policies leading to immigration restriction in both the US and Australia (see for example the US Immigration Act of I89I and the Australian Immigration Restriction Act of 190I). These settler colonial policies became "mechanisms for the exclusion of different races and religious and cultural groups from the immigration process or, in the case of indigenous peoples, bred out," thus allowing for the reproduction of the dominant white culture (Meekosha 2006, 165). 
Natasha Pinterics outlines the moral panic regarding the transmission of corruption between fat mothers and their children, drawing parallels with the conflation of gay men and HIV:

Self-satisfaction through the drives of appetite for food or for sex, particularly sex outside of hetero-nuclear familial norms, are often referenced in terms of potential damage to children, through tropes of figurative (or sometimes literal) contagion. Such contagion discourses mirror those of the North American AIDS panics of the I980s (Van Esterik), which singled out particular (queer male) bodies as excessive in desire, and quite literally contagious with HIV as a result of this excess. (2020, 192).

Therefore, even in popular discourse, viruses such as COVID-I9 are intrinsically linked to non-viral phenomena such as obesity, autism, smoking, poverty, or violent crime, all which are also referred to as epidemics. In this paradigm anything that is "othered" is aligned with danger and disease, painted as the enemy and pitted against the "healthy" innocent body (Ferri 20I8, 66).

The fight against a virus relies on these clearly-drawn borders between "us" and "them;" "good;" and "bad;" "clean;" and "contagious;" and while one is clearly a biological contagion and the others are social, the similarities in social responses to the queer and post-COVID bodies transcend biopolitical lines.

Infectious disease in particular requires an other that can be identified, targeted, and quarantined. Fueled by fears of contagion, 'individuals, groups, populations, locales (regional and global), behaviors, and lifestyles'

(Wald) have all been stigmatized and scapegoated as themselves diseased.

(Ferri 2018, 66)

As Ferri notes, the response to this fear often results in "a commingling of medical, moral, and political panic" (2018, I). As queer bodies we are already viewed as foreign: by destabilizing normative gender and sexuality, queers act as enemies of the state and are therefore already caught up in this moral panic. This was therefore unfortunately already a familiar space for our family to be inhabiting. However, we were not familiar with the scale or the intensity of the panic as it spread rapidly throughout our community. The parents at my child's kindergarten in particular were susceptible to this hysteria and overnight we went from friends to foes-parents hounded us on social media demanding to know the details of our situation, people from our local town wrote accusatory posts on Facebook, and fuelled by anger and fear word spread fast through the wider 
local community about our COVID status. The battle lines had been drawn. It was a clear-cut case of them-the hospital staff, the general public, and even in some cases our friends-versus us, the face of COVID.

Stigma in relation to fat, disability, race, or queerness acts to contain, to prevent the spread of contagion. Likewise, COVID stigma serves to contain survivors of the virus in an attempt to prevent the contamination of the wider population. As Margrit Shildrick maintains, "a contaminated object is one to be avoided or kept at a safe distance, lest we too become affected, our bodies opened up to the forces of disintegration" (2002, I54-155), a sentiment which accurately depicts my family's experiences post-quarantine. Due to a fear of being contagious merely by association, fat people and queers are regarded warily, a state of contagion which is unresolvable and therefore, unlike with contagious illnesses, has no expiry date. There is no point at which the fat or queer body can reach immunity from itself, or acquire the status of no longer being contagious. The contagion, and the accompanying stigma, is indefinite. Despite being no longer medically contagious, post-COVID survivors too are treated as though they are permanently contagious, "othered" by medical professionals, the general public, and even in some cases by friends and family. Phrases such as "undetectable" and "infection periods" are bandied around in COVID dialogues but in reality mean little in regard to indemnity. Weeks, and in some cases even months after receiving our negative test results and being declared by authorities as being no longer a risk, we were still at times being treated with deep suspicion. Fear was the overwhelming emotion running through the general public's veins in those early days when so much was unknown, and this was to some extent understandable. However the postCOVID body is treated in a similar way to that of queer or crip bodies, with a mistrust that masquerades as fear of contagion but which is actually based in a fear of the other.

\section{Stigma and Queer Quarantine}

As a white, (relatively) young queer woman in Australia I have had a comparatively privileged experience of growing up queer-I have never experienced physical violence, nor have I ever been systematically segregated or criminalised for my sexuality. However as queers we are perpetually aware of our vulnerabilities and of the systemic violence, both historical and current, that is perpetrated against LGBTQ+ people. Hate crimes and gay bashings continue to occur across the world, laws are made and upheld to restrict our freedoms and limit our 
rights, and the most vulnerable LGBTQ+ people such as those who are not white, English speaking, or cis gendered, are routinely confined to or banished from both public and professional spaces ${ }^{1}$. Despite this awareness it took me a while to identify the correlations between my experiences as a queer woman and my post-COVID life. Walking down the street of my small country town post-COVID, hand in hand with my partner, I felt uneasy. This was not a particularly alien space for us, as country queers, but it was not until I ran into an older gay friend of mine one day who told me he empathised because he had been around during the height of the AIDS crisis, that I finally made the connection. The stigma we were experiencing was reminiscent of the stigmatizing correlation between queers and HIVIAIDS, and once he had pointed this out to me it was difficult for me to separate the two. My partner and I now represented a threat in two very different ways: both as sexual outlaws, threatening the future of the nation with our challenge to heteronormativity, and as a biological threat to seemingly "healthy" bodies.

These latter sentiments are reminiscent of Lee Edelman's "reproductive futurism," wherein the figure of the Child, in whose name queer people have been vilified and denied rights, represents the stubborn and unwavering investment in child protection discourse that "invariably shapes the logic within which the political itself must be thought ... preserving in the process the absolute privilege of heteronormativity by rendering unthinkable ... the possibility of a queer resistance to this organizing principle of communal relations." (Edelman 2004, 2)

Edelman places the Imaginary futurity of the Child in opposition to the radical negativity of the death drive, a negativity that threatens political accountability and which is figured by the queer, or by sinthomosexuality (Edelman 2004, 6). In excluding those who are thought to reject or threaten this imagined "future"-queers, the contagious-the capitalist hetero-patriarchy remains intact. To this extent, our queer post-COVID-bodies were figuratively assigned their "rightful" association with the death drive, further exacerbated by our refusal to partake in "responsible civic citizenship" by donating our blood to future COVID-I9 patients, which will be expanded on later in this paper by way of biocitizenship.

Due to our history of and current association with contagion we posed a double threat to the well-being and social fabric of society, yet as Plummer and McCann note, the truly dangerous contagion is the response of the community: "...while queerness isn't scientifically transmissible, the fears and prejudices themselves are potentially contagious and highly dangerous" (50). And it was 
these prejudices, despite our release from hospital quarantine, that kept my family in perpetual social quarantine. As with contagion, quarantine is generally understood as having a beginning and an end point. According to Balogh's definition: "If no illness is revealed during the period of quarantine, then the individual is no longer considered to pose a threat to others and is reintegrated into society" $(2015,53)$. However when the quarantine is enforced socially as opposed to legally, this end point can remain elusive. Plummer and McCann (2007) describe queer quarantine as behavioural, such as verbal abuse and physical distancing (46), or political, for example during the AIDS epidemic when the possibility of quarantining all HIV-positive patients, and even branding people to identify their status (50), was considered.

Although our experiences were a far cry from HIV-related quarantining, the at times negative response from friends, the public, and from the school effectively meant that our citizenship was at least in part suspended. There was a strong sentiment that our family should all just "stay at home" because we had been deemed unsafe. Of course while I have drawn similarities between our experience and the stigma experienced by HIV-positive people during the HIV crisis it is imperative to note that, as discussed in more detail later, the HIV crisis was generally ignored by the media, and treated both medically and fiscally as being a "gay problem," whereas COVID has had a strong united global response, continual focused media attention, and a massive amount of financial and medical support. In turn this has meant that there is a general sense of global solidarity regarding the virus that was hugely lacking in relation to HIV, seen for example in the "we're all in this together: get tested, stop the spread" government campaigns being run here in Australia. The interesting thing to note, however, is that for those people like myself who contracted COVID-I9 in the early days of the pandemic, the solidarity seems to end with the rhetoric, surpassed by suspicion and a sense of self-preservation (Stockman, 2020). The threat to mental health this level of social isolation poses is indisputable.

In his thesis on queer quarantine Péter Balogh acknowledges the:

longstanding conflation of queerness with disease and contagion and build[s] a case for reading the isolation, containment and casting out of queerness as an assemblage of discursive tactics and technologies aimed at quarantining queers beyond conventional understandings of quarantine (2015, ii)." 
Quarantine, Balogh says, does not stop at disease. Rather, it is also "deployed against internal "others" deemed dirty, weak, lazy, and improperly gendered and sexualized: Indigenous people, immigrants, racialized people, the working class and poor people" $(2015,70)$, and, of course, queers. The political quarantining of queers is then consequently translated into homophobic policies. Balogh references times when homosexuality has been categorized as either a "crime or mental illness, and works that examine the emergence of the conflation of homosexuality with pedophilia" $(2015,25)$, through to the medical and legal surveillance of queers during the HIV/AIDS crisis and the still-current ban on blood donation for gay men. "Increased state obsession with national security in the era of homonationalism sees a renewed focus on queer threats to the nation's future, for example, via children and the national blood supply" (Balogh 2015, ii-iii), these queer threats being Edelman's "sinthomosexuals" who in refusing the Child refuse the future of the nation itself (Edelman 2004). The rallying cry is therefore that queers must be controlled: "the contagion model ... has at its core a belief in the immorality of same-sex sexuality and the essential charge that homosexuality must be contained" (Knauer 2000, 500), and this applies to post-COVID bodies too.

Examples of queer quarantine in Australia include the historical police raids on beats and gay venues, and more recently the rejection of the Safe Schools Program, which had sought to bring LGBTQ+ education into the classroom to break down stigma and support diverse students, the 2017 Australian Marriage Law Postal Survey, in which the legitimacy of same sex relationships was up for national scrutiny, and the Religious Freedoms Bill, which if passed will allow religious schools to discriminate against LGBTQ+ teachers and also students. One example of queer quarantine which spans both of these eras is the blood ban, where men who have sex with men are currently banned in Australia from donating blood for twelve months following a sexual encounter due to their perceived HIV risk. ${ }^{2}$ These examples all have impacts on sexual citizenship.

In his book, Banning Queer Blood: Rhetorics of Citizenship, Contagion, and Resistance (2009), Jeffrey A. Bennett describes blood donation as "an especially intimate form of civic participation" (III), and argues that denying gay men the right to exercise this civil liberty (I7) is both stigmatising and "hazardous for democratic culture" (246). Just as science overwhelmingly and repeatedly proved that my family were no longer contagious, a fact which was regarded with deep mistrust by the majority of people we encountered once leaving quarantine, science has now developed procedures to ensure that HIV-positive 
donated blood is detected and removed from the blood banks before being passed on to patients (Bennett 2009, 28). However, these two examples show that science seems not to be trusted. Just as all gay men are regarded as being HIV-positive when it comes to blood donation, my family was regarded as being indefinitely COVID-positive. Prejudice triumphs over epidemiological knowledge (Bennett 2009, 3-4; I6), "elucidate[ing] the very vanishing point of citizenship that queers confront daily" (I6).

Following the health authority's declaration that we were no longer contagious, my family found ourselves in an interesting double-bind regarding our bodily fluids. People we met in the streets who knew our story physically moved away from us, presumably to avoid contact with any saliva or mucus or droplets that might escape and contaminate them. On the other hand, drug companies were baying for our blood to use in experimental trials on people suffering from COVID. Society did not want us, but the blood banks did. This is inverse to the experiences of prejudice that gay men encounter regarding blood donation. In response to this prejudice Bennett draws up a battleground of public health versus civil liberties, public health clearly the winner in this round (2009, 4; I8; 32-33). As Bennett suggests, the term "public health" implies "for the good of all people," but this "positioning invites oversight and marginalization" (2009, 33)

Looking at our situation purely from the definition of public health that Bennett outlines, in the interests of public health there would have been an expectation that I would donate my blood to help future COVID patients. However, as a result of the cool reception as we remerged into the world I was less than enthusiastic to participate in my civic citizenship. My family and I were caught in a public health maelstrom where we were not deemed safe, but where we were concurrently deemed vital to combating the virus, and in this battle there were no winners - we were awarded no "immunity passport." While in regard to blood donation during the height of the HIV/AIDS crisis "the medical community had to rhetorically establish that queer men could best practice citizenship by withholding donations" (Bennett 2009, 32), in our situation it was made clear that the best way we could practice our citizenship was to stay at home in indefinite quarantine.

This double-bind can be understood, in part, by theories of biocitizenship. Originally coined by Adriana Petryna (2013) through her ethnography of the Chernobyl disaster, Life Exposed, biocitizenship refers to the complex bureaucratic process whereby a biologically injured population stakes claims to individual and collective social welfare, rendering health (and access to it) a negotiated 
realm of entitlement and exploitation. For example, had I not in my distressed state threatened to leave my room in order to visit my partner and newborn, they may not have been moved to the neighbouring wall the next day and my child and I may also not have been granted the small entitlement to see them daily from thereon. These negotiations with health care professionals were fundamental to our mental and emotional wellbeing.

The concept has since been adapted by a variety of scholars (Clarke et al. 2003; Heath, Rapp and Taussig 2007; Lock 20I0; Petersen I996; Rabinow 20I0), a major source being political scientists Nikolas Rose and Carlos Novas (Rose 2007; Rose and Novas 2008). For Rose (2007), corporeality is essential to personal and social practices of identity, and as citizens, individuals have a set of biological responsibilities concerning health behaviours. Rose borrows the term "biocitizenship" from Petryna to emphasize that health behaviours of individuals are profoundly political acts with society-wide repercussions. Underlying biocitizenship is the idea that as shifts in biomedicine occurred and empirical research began to drive clinical practice, "biological presuppositions, explicitly or implicitly, ... shaped conceptions of what it means to be a citizen, and underpinned distinctions between actual, potential, troublesome, and impossible citizens" (Rose 2007). Citizenship projects are increasingly linked to "beliefs about the biological existence of human beings, as individuals, as families and lineages, as communities, as population and races, and as a species" (Rose and Novas 2008,440 ). I would like to extend this assertion to propose that despite our newfound biological immunity, the social stigma attached to our post-COVID (and queer) bodies, alongside our hesitance to donate blood and our arduous negotiations with health care professionals during quarantine, rendered us permanently "troublesome" citizens.

This impasse is further bound up with discourses of risk and responsibility. Rose and Novas (2008) suggest that corporeality is central to personal and social practices of identity and, as citizens, individuals have a series of biological responsibilities regarding health behaviour, which are embodied in norms surrounding health and practices of health education. These responsibilities stem from the biopolitical discourses of risk and self-preservation that have emerged as basic tenets of neoliberal rationality, and require that "good citizens" manage their own relationship to risk through "self-surveillance," "self-help" (Petersen 1996) and "genetic prudence" (Rose and Novas 2008). Individuals whose behaviour is deemed contrary to risk-free or prudential norms are seen as lacking self-control (including fat people and queers, as noted by Pinterics 2020), 
and not fulfilling their duties as responsible citizens. The health behaviours of individuals are therefore fraught with moral judgements regarding "distinctions between good and bad subjects of ethical choice and biological susceptibility" (Rose and Novas 2008, 442), and consequently they are deeply political acts with repercussions for society as a whole. These norms operate within a "political economy of hope" in which life itself should be capitalized on. Investments in the future scientific discovery of cures and treatments for human diseases create and depend upon a "hopeful domain of activity" that stipulates an "active stance toward the future" (Rose and Novas 2008, 452). Maintaining an "active stance towards the future" requires that one has a foreseeable future to begin with, and for queers, particularly trans, Black, Brown, and non-white queers, this has historically not been a given.

\section{A Comparison of the Public Response to HIV and COVID-19}

Rhetorics of "we are all in this together" butt heads against the "us" and "them" dichotomy that suddenly appeared between my family and the general population when we contracted COVID. Our status as queers in a small regional town had already required various forms of social distancing unrelated to and yet amplified by our COVID status, which in turn had detrimental impacts on our wellbeing by further emphasising our aberrations and leaving us feeling more "othered" and isolated than we had before. Hence the sentiment of "solidarity" is misleading for those who are already so keenly aware of their position on the outer of their geographical communities. While public health officials assure us "we are all" socially distancing to flatten the curve, psychosocial, physical, and moral distancing for groups already marginalized by structural inequality is not new (Bowleg 2020). Research shows that response to the pandemic has created even greater isolation, increased health disparities, and lack of support for LGBTQ+ populations when compared with their heterosexual counterparts (Gibb et al. 2020; Hafi and Uvais 2020; SAGE and HRC 2020). LGBTQ+ youth experience general and identity-specific stressors as a result of COVID-I9, such as concerns about being confined at home with unsupportive family members and the inability to access supportive resources (Fish et al. 2020). This applies also to LGBTQ+ adults due to the closure of many gay venues and spaces, resulting in a lack of peer support and increased co-mingling with family or housemates with whom they may not be comfortable (Hafi and Uvais 2020). LGBTQ+ people face mental health disparities such as increased anxiety, depression, PTSD, and 
suicidality, which may be exacerbated as a result of COVID-I9 pandemic trauma and social isolation measures (Salerno, Williams and Gattamorta 2020).

Therefore, while ostensibly benign and often well intentioned, these sentiments of solidarity obscure the existing structural inequities faced by queer, non-white, trans, gender non-conforming, and other marginalized groups who suffer disproportionately from any global issue, be it climate change, poverty, HIV/AIDS, and most recently, COVID-I9. However, imperfect as the global solidarity towards COVID-I9 may be, as mentioned earlier the response has been far worse for previous pandemics, such as the AIDS pandemic, where social determinants were similarly useful in determining risk, treatment, and stigma. While COVID public health responses do have the capacity to overlook and/or exacerbate stigma amongst marginalized populations, unlike AIDS they have represented COVID as a "universal threat." Health authorities at all levels have maintained that COVID is a virus transmittable by and to all humans, despite groups at the intersections of race, poverty, and geographic location experiencing much higher risk. ${ }^{4} \mathrm{HIV}$, on the other hand, has historically been associated with particular demographics; namely, as Moore points out: "gay men, people of colour and intravenous drug users" (Moore 2020). The moral panic that ensued, bolstered by the homophobia of the eighties and early nineties, came to situate gay men as synonymous with death and contagion, and the virus itself as a "gay plague" (Quinn et al. 2020). This was reaffirmed by the lack of medical and governmental action at the time, and the overall political silence that came to define the epidemic. One could argue that the incredible response we have seen towards COVID-I9 is largely due to the fact that it does impact the majority - if AIDS had primarily impacted the straight, white, non-intravenous-drug-using middle class we would likely have witnessed a very different response.

On a personal, level my awareness of this history, combined with the false "we're all in this together" rhetoric of solidarity surrounding COVID was hard to stomach given that historically "those who bear the intersectional brunt of structural inequality" are elided from it (Bowleg 2020). As mentioned earlier, the individual responsibilization of health behaviours and attitudes stems from biopolitical discourses of risk that place individuals at the centre of structural (and global) health crises ("wash your hands," "wear a mask," "maintain I.5 metres," etc.), becoming a basic tenet of neoliberal rationality (Rose 2007). 
As Bennett acknowledges in his examination of the discriminatory blood donation laws, this policing of bodies, or even, arguably, this situating of bodies as a threat:

illustrates a complex cultural management, a disciplining of citizenship and its affiliation with performances of nationalism. Constructing queer identity through representations of diseased and undisciplined sexuality, the state mobilizes rhetorics consistent with Iris Marion Young's disconcerting observation that queer people are perhaps the most abject Other in the United States (2009, I6).

As Plummer and McCann outline in "Girls' Germs: Sexuality, Gender, Health and Metaphors of Contagion," this concept of the threatening gay body perhaps has its roots in the HIV/AIDS crisis and the subsequent moral panic, which presented a unique situation where the fear of contagion was combined with both the fear of "a virus and of sexual difference" $(2007,44)$, unequivocally marrying the two in unhappy harmony.

This is particularly salient given the enduring effects of the HIV/AIDS pandemic, which still causes disproportionate pain, suffering and death amongst LGBTQ+ communities today. "These experiences and histories help to anchor queer experiences of COVID-I9" (Rethmann 2020, I). It is necessary to consider, then, how COVID affects those with already stigmatised sexual orientations and gender identities (SOGI) due to the historical and bio-medical regulation of queer bodies as second-class citizens. As with AIDS, fear of COVID is articulated by an anxious distancing and condemnation of it; a fear of the abject-bringing the shame of non-normative sexual or gender identity into a shared frame with the real or imagined risk of COVID contagion. As Argüello points out in relation to HIV, "we are not just at war with a microscopic virus. We are also in an "epidemic of signification:" we are in a battle over meaning, power, discourse, culture, and bodies. The virus attaches not only to genetic processes, it harnesses social discourses and capitalizes on operating dynamics of marginalization" (Argüello 2016, 7, emphasis added). Correspondingly, COVID draws attention to differences across gender and sexuality-but also race, class, ability, age, and so forth-foregrounding social inequities.

\section{Queer Temporality}

Living in (social) contagion, even after recovery from COVID-I9, can be understood as a queer time warping experience (Stacey and Bryson 20I2). "Queer 
time," or queer temporality, opens up alternative relations to heteronormative linear temporality. It is a means for thinking through the "timing" of queerness, and of queerness in relation to the temporality of lived experience. Queer theorist Jack Halberstam argues that queer models of time and space emerge outside of the "temporal frames of bourgeois reproduction and family, longevity, risk/ safety, and inheritance" (Halberstam 2005, 6). Queerness itself is "an outcome of strange temporalities, imaginative life schedules, and eccentric economic practices" (Halberstam 2005, I). By contrast, "straight time" regulates sexual orderings by legitimizing the heteronormative social processes that structure how we live and imagine everyday life (Stacey and Bryson 2012). Just as everyday queer life fosters alternate temporal schemas, the pandemic has disrupted our seemingly ordinary cultural tempos and routines. Time has slowed almost to a standstill yet feels busier than ever; with many facets of work, leisure and life confined to the home, the parameters of the eight-hour workday become increasingly ambiguous. An inordinate amount of time is spent refreshing browsers, counting numbers, keeping up on the endless cycle of restrictions. In many ways, the anxiety of living in the present with its setbacks and small, hardearned silver linings "undoes any certainty of predictive futurity" - not unlike those horizons diminished by the AIDS epidemic at the end of the twentieth century (Stacey and Bryson 20I2, 9). Simultaneously, it has invoked "a desire for another way of being both in the world and in time, a desire that resists mandates to accept that which is not enough" (Muñoz 2007, 365). Or as Halberstam puts it, this unknown future demands:

[a] new emphasis on the here, the present, the now, and while the threat of no future hovers ahead like a storm cloud, the urgency of being also expands the potential of the moment and...squeezes new possibilities out of the time at hand (Halberstam 2005, 2).

In doing so, COVID's time warp reveals the false promise of heteronormative linear temporality, or of the predictability of futurity. "Queer time" shifts presence into a disjointed register- "in so doing, perhaps all it can show us is the problem of apprehending time's uncanny unknowability and of coming into proximity with our own materiality and thus, of course, our own mortality" (Stacey and Bryson 2012, 15).

While any illness warps time to some extent, ${ }^{5}$ COVID-I9 does so in particular ways through the combination of its initial uncertain presence (asymptomatic, "flu"-like symptoms), its uncertain mobilities (we currently know very little about it, comparative to other viruses), its lingering stigmatization (despite 
recovery, as if the "walking dead") and unpredictable future (life does not return to "normal," even by homonormative standards). Our family's story upsets "any conventional sense of time's linear, causal dynamics, offering instead the perceptual disturbances that mark a body returned to its present through the physical and emotional demands of life-threatening illness." (Stacey and Bryson 20I2, 6). This liminality represents a body "living in prognosis"-on the threshold between wellness and disease (Frank 1991; Jain 2007; Sinding and Gray 2005), a concept developed by Jain (2007) to explore the temporality of cancer survivorship-a term itself which resonates a concurrency of both life and death. We propose that the queer temporality of prognosis is a useful space from which to understand the post-COVID body, where similarly:

one's future will only be absorbed into the truth of prognosis, a truth that recursively projects a future as it acts as a container for a present. The prognosis offers an abstract universal, moving through time at a level of abstraction that its human subjects cannot occupy, and in so doing it threatens to render us all ... inert. (Jain 2007, 79)

Throughout the course of our COVID-I9 experience, we have been living in the time warp of prognosis. From the time of diagnosis through to our hospitalization and quarantining, and including our state-sanctioned "recovery," there has been no narrative coherence. There can be no linear conception of wellness-torecovery due to the ongoing stigmatization associated with the virus, and which resonates with queer histories of contagion. While prognostic time does anticipate a future, "one's future will only be absorbed into the truth of prognosis, a truth that recursively projects a future as it acts as a container for a present" (Jain 2007, 79).

COVID queered time in terms of our recovery from the virus, positioning our bodies as sites of permanent contagion and subsequent stigmatization which I experienced as akin to homophobic attacks. Six months post-COVID my family and I are still at times subject to stigma and treated with fear and suspicion, causing more harm to our health than the virus. However a final point to make on this is the current lack of knowledge regarding medical immunity and COVID-I9. News articles every few days spout theories on how long immunity lasts for, how effective a vaccine will be, whether it is possible to be reinfected, and whether a second round of COVID will affect the body more mildly or worse than the last. My own fear of a second infection, of becoming contagious once again, is compounded by the fear of contagion still being projected on to me by those around me. Every time I sneeze it triggers a chain 
of thoughts that starts with mentally tracing everyone I have recently been in contact with, and ends with planning what toys to take in to hospital this time to keep my child better entertained. But in addition to this retriggering of trauma is my fear that next time we will not be so lucky-that next time my partner's lungs will give out, or his child will not be able to be revived. I treat myself with suspicion the same way that others still do, but while they can move away on the street or avoid us in the park, for me the threat is within me, like an autoimmune disease lurking, waiting to attack. I fear my own contagion.

As Ferri notes in "Metaphors of Contagion and the Autoimmune Body," autoimmune disease sits outside the paradigms of cure that prevail in most medical dialogues, and similar to COVID the contagion has no end point. Drawing on philosophies first formulated by theorists Derrida and Tsai, Ferri makes the point that, as with autoimmune disease, self-destructive responses to external threats often result in harming the self, itself (or rather the nation in her analogy). She uses as an example the censorship and surveillance of American citizens that resulted from the 9-II terrorist attacks in the United States $(2018,7 \mathrm{I})$, but this is also applicable to the COVID response, where isolation and segregation are frequently conflated with or mistaken for safety. The sense of "us" versus "them" is once again challenged when the threat comes from inside you, and the great contradiction in my own situation at least, is that as with autoimmune disease "the victim and the villain are the self/same" (Ferri 20I8, 65). And of course, there is no escaping the self.

\section{Holly Zwalf,}

Independent Researcher,

h.zwalf@unswalumni.com

\section{Samantha Sperring,}

University of Technology Sydney,

samantha.sperring@uts.edu.au 


\section{Notes}

I For some examples see the US military's “Don't Ask, Don't Tell” policy regarding LGBTQ+ people in the military, and also Vitulli (20I8) who writes about homosexual men being separated in US prisons over the decades (2I-45).

2 To further highlight the discrimination displayed by the blood banks, in Australia trans women and men are also banned from donating blood for a year after having sex with a cis-gendered man. Straight women, however, can have sex with as many cis-gendered men as they want and continue to donate their blood.

3 As a result of the trauma we experienced while in hospital quarantine our familial relationships have suffered, and we have all sustained long-lasting mental health issues. In addition, for several weeks following our release from hospital, Public Health rejected my requests to visit my partner and the baby due to quarantine regulations. It is clear that mental health is not considered an essential part of health services, and I would therefore argue that the concept of what constitutes "good" health clearly needs to come under deeper scrutiny.

4 Thanks to an anonymous reviewer for raising this important point.

5 As is explored by Stacey and Byron's (2012) compelling theorisation on the temporality of cancer survivorship.

\section{References}

Allen, Jafari Sinclaire. 20I6. "One View from a Deterritorialized Realm: How Black/ Queer Renarrativizes Anthropological Analysis." Cultural Anthropology 3I (4): 6I7-626. https://doi.org/IO.I4506/ca3I.4.IO.

Argüello, Tyler M. 20I6. "Fetishizing the Health Sciences: Queer Theory as an Intervention." Journal of Gay and Lesbian Social Services 28 (3): 23I-244. https://doi. org/I0.I080/10538720.20I6.II9I407.

Balogh, Péter. 2015. Queer Quarantine: Conceptualizing State and Dominant Cultural Responses to Queer Threats as Discursive Tactics and Technologies of Quarantine. Master's thesis, Carleton University.

Bennett, Jeffrey A. 2009. Banning Queer Blood: Rhetorics of Citizenship, Contagion, and Resistance. Tuscaloosa: The University of Alabama Press.

Bowleg, Lisa. 2020. "We're Not All in This Together: On COVID-I9, Intersectionality, and Structural Inequality." American Journal of Public Health IIo (7): 917-9I7. https:// doi.org/I0.2105/AJPH.2020.305766. 
Clarke, Adele, Janet Shim, Laura Mamo, Jennifer Fosket, and Jennifer Fishman. 2003. "Biomedicalization: Technoscientific Transformations of Health, Illness, and U.S. Biomedicine." American Sociological Review 68 (2): I6I-I94. https://doi.org/I0.2307/ 1519765.

Ebben, Hannah. 20I8. "The Desire to Recognize the Undesirable: De/Constructing the Autism Epidemic Metaphor and Contagion in Autism as a Discourse." Feminist Formations 30 (I): I4I-I63. https://doi.org/I0.1353/ff.2018.0007.

Edelman, Lee. 2004. No Future: Queer Theory and the Death Drive. Durham: Duke University Press.

Ferri, Beth A. 2018. "Metaphors of Contagion and the Autoimmune Body." Feminist Formations 30 (I): I-20. https://doi.org/IO.I353/ff.20I8.oooI.

Fish, Jessica, Lauren McInroy, Megan Paceley, Natasha Williams, Sara Henderson, Deborah Levine, and Rachel Edsall. 2020. "I'm Kinda Stuck at Home With Unsupportive Parents Right Now': LGBTQ Youths' Experiences With COVID-I9 and the Importance of Online Support." Journal of Adolescent Health 67 (3): 450-452. https://doi.org/IO.IoI6/j.jadohealth.2020.06.002.

Frank, Arthur W. 199I. At the Will of the Body: Reflections on Illness. Boston: Houghton Mifflin.

Fritsch, Kelly, and Anne McGuire. 2018. "Introduction: The Biosocial Politics of Queer/Crip Contagions." Feminist Formations 30 (I): 2I-45. https://doi.org/IO.I353/ ff.2018.00oo.

Gobo, Giampietro. 2008. Doing Ethnography. Translated by Adrian Belton. Los Angeles: Sage.

Gibb, James, Zachary DuBois, Sarah Williams, Luseadra McKerracher, Robert-Paul Juster, and Jessica Fields. 2020. "Sexual and Gender Minority Health Vulnerabilities during the COVID-19 Health Crisis." American Journal of Human Biology 32 (5): e23499. https://doi.org/IO.IOO2/ajhb.23499.

Gibson, Margaret F. 2018. "Subtle Neglect and Yuckiness: Queerness, Disability, and Contagion in Mother Narratives." Feminist Formations 30 (I): II7-I4O. https://doi. org/IO.I353/ff.20I8.0006.

Hafi, Bishurul, and N.A. Uvais. 2020. "Difficulties Faced by Sexual and Gender Minorities during COVID-I9 Crisis." Psychiatry and Clinical Neurosciences 74 (8): 444. https://doi.org/IO.IIII/pcn.I308o. 
Halberstam, Judith. 2005. In a Queer Time and Place: Transgender Bodies, Subcultural Lives. New York and London: New York University Press.

Heath, Deborah, Rayna Rapp, and Karen-Sue Taussig. 2007. “Genetic Citizenship.” In A Companion to the Anthropology of Politics, edited by David Nugent and Joan Vincent, 152-167. Hoboken, UK: John Wiley and Sons, Incorporated.

Human Rights Campaign Foundation (HRC), 2020. The Lives and Livelihoods of Many in the LGBTQ Community Are at Risk amidst COVID-I9 Crisis. https:/www.hrc.org/ resources/the-lives-and-livelihoods-of-many-in-the-lgbtq-community-are-at-riskamidst-covid-I9-crisis

Jain, Lochlann. 2007. "Living in Prognosis: Toward an Elegiac Politics." Representations 98 (I): 77-92. https://doi.org/IO.I525/rep.2007.98.I.77.

Knauer, Nancy J. 2000. "Homosexuality as Contagion: From the Well of Loneliness to the Boy Scouts." Hofstra Law Review 29 (2): 4OI-50I. http://scholarlycommons.law. hofstra.edu/hlr/vol29/iss2/2.

Lock, Margaret, and Vinh-Kim Nguyen. 20I0. The Anthropology of Biomedicine. Malden, MA: Wiley-Blackwell.

Meekosha, Helen. 2006. "What the Hell Are You? An Intercategorical Analysis of Race, Ethnicity, Gender and Disability in the Australian Body Politic." Scandinavian Journal of Disability Research 8 (2-3): I6I-I76. https://doi.org/IO.IO80/150I74I0600831309.

Moore, Sam. 2020. "It’s Time to Stop Comparing COVID-I9 to HIV." Xtra, 29 July. https:// www.dailyxtra.com/covid-I9-hiv-aids-comparisons-I76602?fbclid=IwAR3uxKHd_tSEUwvYdzB_XX_l3Pt6nhN6eFCz4sfysNiPi3vFceSR-6FSGYg (accessed I2 February 202I).

Morgensen, Scott L. 20I6. "Encountering Indeterminacy: Colonial Contexts and Queer Imagining.” Cultural Anthropology 3I (4): 607-616.

Muñoz, José Esteban. 2007. "Cruising the Toilet: LeRoi Jones/Amiri Baraka, Radical Black Traditions, and Queer Futurity." GLQ: A Journal of Lesbian and Gay Studies I3 (2-3): 353-367. https://doi.org/IO.I215/I0642684-2006-037.

Newmahr, Staci. 20II. Playing on the Edge: Sadomasochism, Risk, and Intimacy. Bloomington: Indiana University Press.

Petersen, Alan R. 1996. "Risk and the Regulated Self: the Discourse of Health Promotion as Politics of Uncertainty." Australian and New Zealand Journal of Sociology 32 (I): 44-57. https://doi.org/IO.II77/144078339603200I05. 
Petryna, Adriana. 2013. Life Exposed: Biological Citizens after Chernobyl. Princeton: Princeton University Press.

Pinterics, Natasha. 2020. "Excessive Maternal Embodiment: The Queer Danger of Desirous Mothers." In Mothers, Sex, and Sexuality, edited by Holly Zwalf, Michelle Walks and Joani Mortenson, I9I-212. Bradford, Canada: Demeter Press.

Plummer, David, and Pol Dominic McCann. 2007. "Girls' Germs: Sexuality, Gender, Health and Metaphors of Contagion." Health Sociology Review I6 (I): 43-52. https:// doi.org/I0.5I72/hesr.2007.I6.I.43.

Quinn, Katherine G., Jennifer L. Walsh, Steven A. John, and Alan G. Nyitray. 2020. "I Feel Almost as Though I've Lived This Before': Insights from Sexual and Gender Minority Men on Coping with COVID-I9." AIDS and Behaviour 25: I-8. https://doi. org/IO.IOO7/sIO46I-02O-03036-4.

Rabinow, Paul. 2010. "Artificiality and the Enlightenment: From Sociobiology to Biosociality." Politix 23 (2): 2I-46. https://doi.org/IO.IO02/9780470775875.ch7.

Rethmann, Petra, ed. 2020. Covid-I9: Urgent Responses, Globalization Working Papers. Hamilton: Institute on Globalization and the Human Condition, McMaster University.

Rose, Nikolas, and Carlos Novas. 2008. "Biological Citizenship." In Global Assemblages, edited by Aihwa Ong and Stephen J. Collier, 439-463. Malden, MA: Blackwell Publishing.

Rose, Nikolas S. 2007. Politics of Life Itself: Biomedicine, Power, and Subjectivity in the Twenty-First Century. Princeton: Princeton University Press.

Salerno, John, Natasha Williams and Karina Gattamorta. 2020. "LGBTQ Populations: Psychologically Vulnerable Communities in the COVID-I9 Pandemic." Psychological Trauma: Theory, Research, Practice, and Policy I2 (SI): S239-S242. http://dx.doi. org/I0.I037/traoooo837.

Shildrick, Margrit. 2002. Embodying the Monster: Encounters with the Vulnerable Self. London: Sage.

Sinding, Christina, and Ross Gray. 2005. "Active Aging-Spunky Survivorship? Discourses and Experiences of the Years Beyond Breast Cancer." Journal of Aging Studies I9 (2): I47-I6I. https://doi.org/I0.IOI6/j.jaging.2004.05.00I.

Stacey, Jackie, and Mary Bryson. 2012. "Queering the Temporality of Cancer Survivorship." Aporia 4 (I): 5-I7. https://doi.org/IO.I8192/aporia.v4iI.292I. 
Stockman, Farah. 2020. "What It's Like to Come Home to the Stigma of Coronavirus." New York Times, 4 March. https://www.nytimes.com/2020/03/o4/us/stigma-coronavirus.html. (accessed I December 2020).

Vitulli, Elias Walker. 20I8. "Dangerous Embodiments: Segregating Sexual Perversion as Contagion in US Penal Institutions." Feminist Formations 30 (I): 2I-45. https:// doi.org/IO.I353/ff.20I8.0002. 